\title{
An Adapted Thermal-gradient Block for the Germination of Photoblastic Seeds
}

\author{
Victor José Mendes Cardoso* \\ Departamento de Botânica; Instituto de Biociências; Universidade Estadual Paulista; Campus de Rio Claro; \\ C. P.: 199; 13506-900; Rio Claro - SP - Brasil
}

\begin{abstract}
This work describes an adapted thermal-gradient block with internal illumination, allowing experiments with lightrequiring seeds. The temperature dependence study on the germination of the photoblastic Plantago tomentosa seeds was carried out in order to test the performance of the apparatus. With the aid of the model described here, some parameters related to the response of the seeds to temperature could be estimated, showing that the apparatus was suitable for the studies on the temperature dependence of photoblastic seeds.
\end{abstract}

Key words: Temperature devices, thermal-biology, Plantago tomentosa

\section{INTRODUCTION}

It has been known that the growth and plant metabolism are strongly temperature dependent. The process of germination involves the interaction among the growth effector (the embryo), the diffusion barriers (the seed coat) and the source of potential energy (the seed reserves), and is highly affected by the temperature (Labouriau, 1978). In general, both the germinability and the germination rate are temperature dependent, hence the germination assays must be carried out at defined temperature regimes. In order to explore the entire range between the cardinal temperatures, many different temperature experiments must by performed simultaneously in order to overcome a possible storage effect between successive experiments on germination (Labouriau, 1977). Thus, the studies on the seed germination response to temperature usually require the use of a large number of growth cabinets which are expensive and occupy a large space. In order to avoid this problem, many authors have designed thermal gradient devices, most of them consist of a aluminum (or other heat-conducting material) bar which is heated at one end and cooled at the other, thus producing a temperature gradient along the length of the material (Brites et al., 1986; Peters, 1990; Thompson and Whatley, 1984; Vasquez-Yanes, 1975;). The seeds or the experimental objects are disposed on the bar, whose surface is covered with substrate, usually a sheet of humid filter paper. An inconvenient of this method is the continuous diffusion of water vapor from the hot to the cold end of the bar, causing one side of the device to dry and the other side to flood. Also, the air convection over the bar can minimize the temperature gradient recorded within the bar, thus affecting the response of large seeds laid on it. Labouriau (1977) and Labouriau and Agudo (1987) reported thermal-gradient blocks whose

\footnotetext{
* Author for correspondence: victorjc@ @rc.unesp.br
} 
design overcame the inconvenient referred above, but the devices was not useful for the seeds whose germination required relatively prolonged light exposure, since the thermal stations of the block did not allow the illumination. Cardoso (1994) designed a thermogradient bar with individualized thermal stations and the advantage of allowing the experimental objects to be exposed to light. However, that device presented a relatively high heat lose between the insulated tanks filled with thermal fluid and the useful area for the germination tests on the bar, thus making difficult to obtain higher and lower extreme temperatures.

Taking into account that the thermal-gradient block described by Labouriau and Agudo (1987) has been proven to be an efficient device in the studies of temperature dependence on seed germination (Santos and Cardoso, 2001; Souza and Cardoso, 2000), the main purpose of this work was to describe an adapted block with internal illumination, allowing temperature assays with the seeds that needed light to germinate (photoblastic seeds). The prototype have been used in previous works (Machado-Neto et al., 2006; Cardoso and Pereira, in press) and proved to be a useful tool in temperature controlled experiments with either photoblastic or non-photoblastic seeds. In this work some thermal parameters of the germination of the photoblastic Plantago tomentosa seeds (Dousseau et al., 2008) were also described.

\section{MATERIALS AND METHODS}

\section{Biological Material}

The seeds of Plantago tomentosa Lam. (Plantaginaceae) were collected from the plants growing on a grass field $\left(22^{\circ} 23^{\prime} 25^{\prime \prime} \mathrm{S}\right.$; $47^{\circ} 32^{\prime}$ ' $2^{\prime \prime}$ W) at Unesp, Rio Claro, São Paulo State. The dry fruits were removed from the inflorescence axis and passed through a fine sieve to remove the seeds, which were stored at room temperature (22$26^{\circ} \mathrm{C}$ ) in glass vials up to one week before they were used for the experiments.

\section{Thermal-gradient block}

An adapted apparatus is presented here which is based on models previously developed and described in details by Labouriau and Agudo (1987) and Labouriau and Cavalcanti (1996). It consisted of successive vertical sets of six $300 \mathrm{~mm}$ - long aluminum tubes separated from each other by aluminum plates (Fig. 1). Solid aluminum rods, which crossed the plates above and below were used for holding the series of tubes and plates together with the aid of nuts for tightening the whole set. Sixty aluminum tubes with a $50.8 \mathrm{~mm} \mathrm{x}$ $38.1 \mathrm{~mm}\left(\cong 2\right.$ " $\times 1 \frac{1 / 2 ")}{}$ rectangular section were used; 13 aluminum plates $300 \mathrm{~mm}$ x $388 \mathrm{~mm}$ x $12.7 \mathrm{~mm} ; 6$ aluminum rods $(\phi \cong 15.9 \mathrm{~mm}) 606 \mathrm{~mm}$ long; and 20 aluminum flat bars $300 \mathrm{~mm}$ long $\mathrm{x}$ $50.8 \mathrm{~mm}$ width $\times 3.18 \mathrm{~mm}$ thick, whose function was to fill the spaces between the rods and upper and lower aluminum tubes. Thus, the main difference between the block described here and previous model (Labouriau and Agudo, 1987) was the larger size of the aluminum tubes. This allowed a better distribution of the light from the fluorescent tubes placed behind the block (see below).

Each of the two lateral faces of the block received an additional aluminum plate $(300 \mathrm{~mm} \times 388 \mathrm{~mm} \times$ $12.7 \mathrm{~mm}$ ) through which the thermal fluid $(20 \%$ water solution of propylene glycol) flowed, driven by a pump of a thermostatic bath. In previous models (Labouriau and Agudo, 1987; Labouriau and Cavalcanti, 1996), the thermal agent circulated through a copper coil tube, embedded in the terminal aluminum plate. In the present model, a groove was milled on the internal surface of each additional plate, which was then glued to the terminal plate at the both sides of the block (Fig. 1). Thus, the thermal fluid flowed in direct contact with the plate, improving the heat exchange between the fluid and the block. A copper tube $(\phi$ $=6 \mathrm{~mm}, 140 \mathrm{~mm}$ long) was connected to the additional plate through a nipple screwed to the hole on the lateral face of the plate both in the "input" and the "output" of the groove (Fig. 2). Such copper tube was used to connect a silicone tube through which the thermal fluid circulated between the bath pump and the block.

The whole block rested on four wooden supports

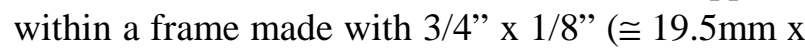
$3 \mathrm{~mm})$ profiles of galvanized iron and covered with

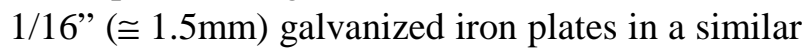
way to previously reported models (Labouriau and Agudo, 1987; Labouriau and Cavalcanti, 1996). The assembly was thermally insulated all around, with the exception of the back face, by a $50 \mathrm{~mm}$ thick polystyrene sheet (Fig 1). 


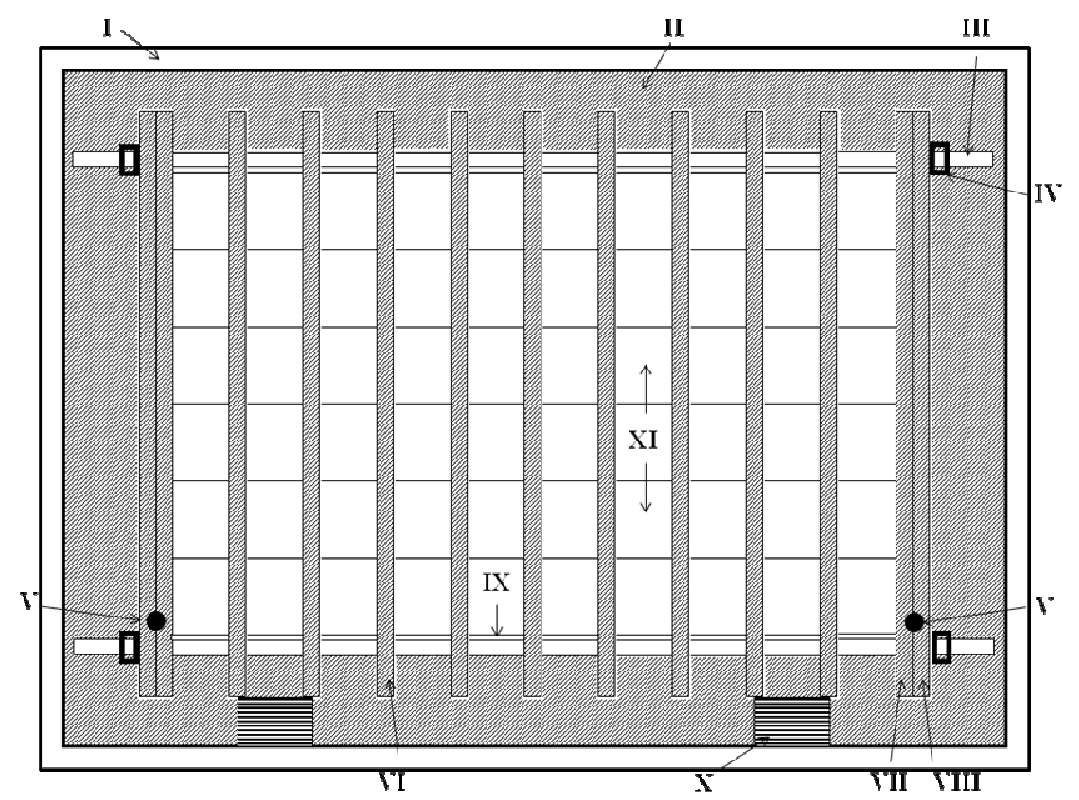

Figure 1 - Frontal view of the assembly of aluminum tubes and plates resting on wooden blocks placed on the bottom of the frame (only two of four blocks are displayed). I: frame (490mm height $\times 675 \mathrm{~mm}$ width $\mathrm{x} 440 \mathrm{~mm}$ deep) made with profiles of galvanized iron. II: insulating polystyrene layers $50 \mathrm{~mm}$ thick. III: one of the six aluminum rods for holding the plates and tubes. IV: one of the nuts for tightening the assembly. V: input of the additional plate within which the thermal agent circulates. VI: one of the intermediate aluminum plates $(388 \mathrm{~mm}$ height $\mathrm{x} 300 \mathrm{~mm}$ width $\mathrm{x} 12.7 \mathrm{~mm}$ thick). VII: terminal plate at one side of the block. VIII: additional plate glued to the terminal plate. IX: one of the aluminum flat bars (300mm long x 30.8mm width x 3,18mm thick). X: one of the four wooden supports (only two can be viewed). XI: a column of rectangular cross-section aluminum tubes (300mm depth $\mathrm{x} 50.8 \mathrm{~mm}$ height $\mathrm{x} 38,1 \mathrm{~mm}$ width), representing a thermal station.

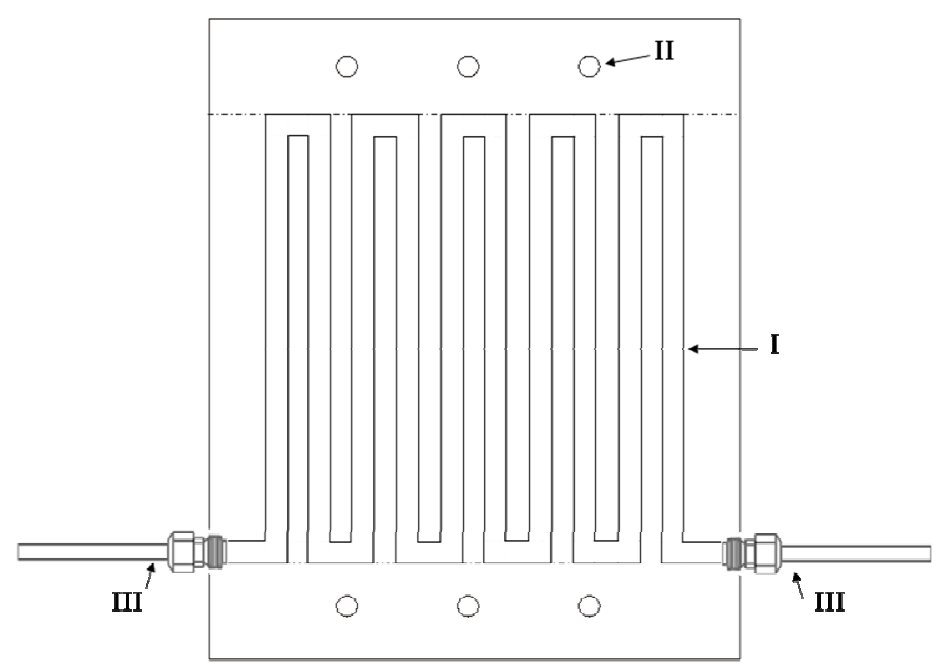

Figure 2 - Scheme of an additional aluminum plate through which the thermal fluid flows in a groove (I) milled on the internal surface of the plate. II: A hole (15.9mm in diameter) for passage of the holding rod. III: copper tube $(\phi=6 \mathrm{~mm})$ connected to the plate through a nipple. 
Each vertical set of aluminum tubes was referred to as a "thermal station" with six repetitions; thus, the tubes were arranged in ten columns, or thermal stations, and six rows or replicates. A set of six $20 \mathrm{~W}$ fluorescent tubes was placed between the rear face of the block and the rear iron plate, with each lamp disposed along a row. The fluorescent tubes were supported by two pieces of $25 \mathrm{~mm} \mathrm{x}$ $50 \mathrm{~mm}$ wood lath fixed to the inner face of the frame according to the scheme (Fig. 3 and 4). The internal surface of the removable lid at the frontal face of the apparatus was covered by a mirror glued to the polystyrene layer (Fig. 4). The mirror reflected the light from the fluorescent tubes placed in the rear face of the block, thus improving the light distribution along the thermal stations. The circulation of the thermal fluid as well as the control of the temperature gradient in the block were provided by two Forma Scientific, model 2095, thermo regulated baths. The model 2095 was a $28.4 \mathrm{~L}$ capacity bath with a temperature range from -20 to $+70{ }^{\circ} \mathrm{C}$, maintaining a constant temperature $\left( \pm 0.02{ }^{\circ} \mathrm{C}\right)$ by means of an ultrasensitive thermoregulator. Constant circulation was provided by a 1/12 HP pump producing $1-1 / 2$ to $2 \mathrm{gpm}$ at zero head and the single stage pump permited closed loop circulation to an external vessel. The temperature variations within the thermal stations were recorded with ten PT100 temperature sensors (JK Instrumentos, ME, Piracicaba, SP), connected to an electronic thermometer (JK model SK 010, JK Instrumentos, ME, Piracicaba, SP). The light measurements were taken with a point LI-190 SA Quantum sensor (LICOR) connected to a LI-1000 datalogger (LICOR).

The finishing of the entire apparatus is displayed at Fig. 5. Similarly to Labouriau and Cavalcanti (1996), the thermal stations were $50 \mathrm{~mm}$ behind the front face of the frame and that space was occupied by the removable lid when the apparatus was closed (Figs. 4 and 5). The galvanized iron plate at the rear face of the frame presented a series of holes through which the temperature probes were inserted into the lowest row of the thermal stations, allowing the temperature to be monitored continuously.

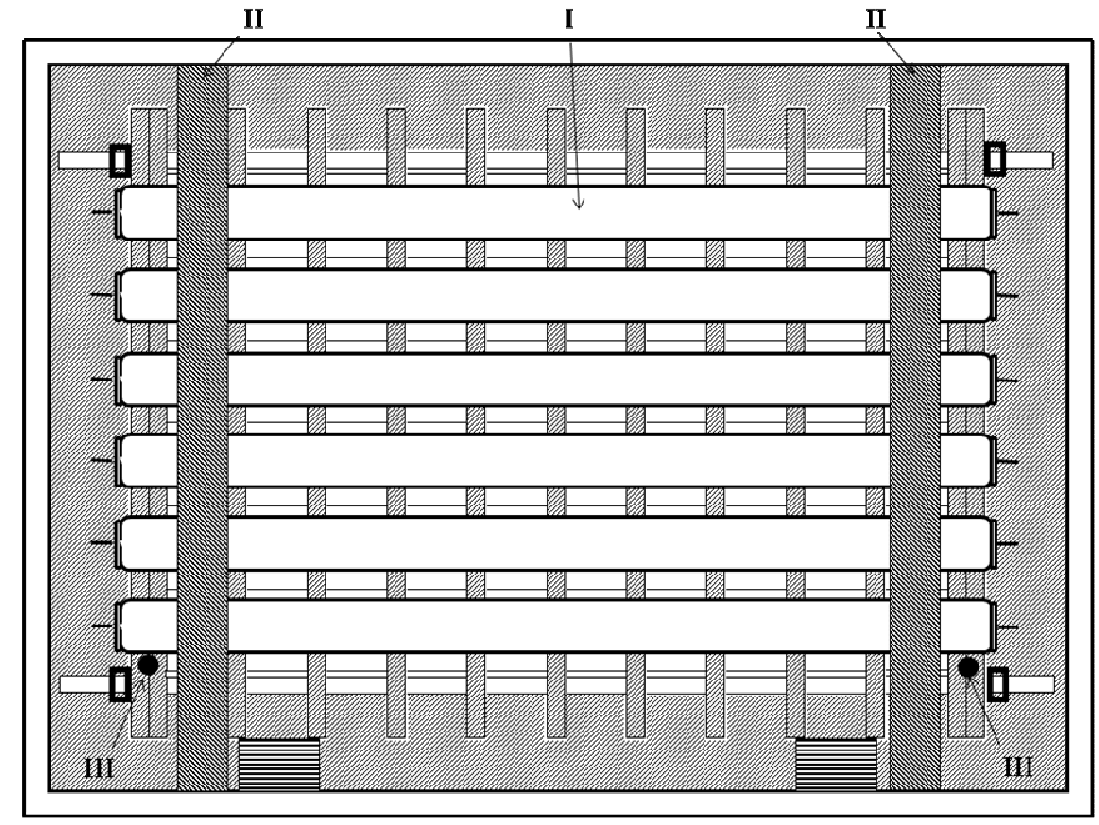

Figure 3 - Back view of the assembly showing the set of six $20 \mathrm{~W}$ fluorescent tubes (I) supported by two pieces of $25 \mathrm{~mm} \times 50 \mathrm{~mm} \times 480 \mathrm{~mm}$ long wood lath (II). III: Output of the thermal agent. 


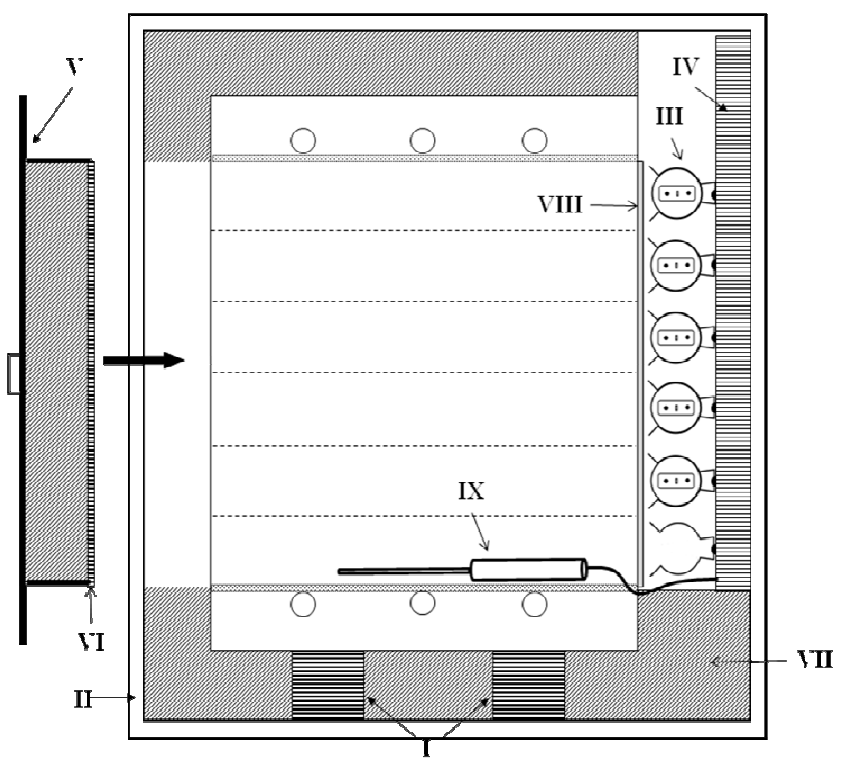

Figure 4 - Lateral view of the block resting on the wooden supports (I) within the frame (II), showing the set of fluorescent tubes (III) supported by the wood lath (IV) at the back side of the apparatus. V: removable galvanized iron lid $(520 \mathrm{~mm}$ width $\mathrm{x} 400 \mathrm{~mm}$ height $\mathrm{x} 3 \mathrm{~mm}$ thick) covered by a $50 \mathrm{~mm}$ polystyrene layer. $\mathrm{VI}$ : mirror $(480 \mathrm{~mm}$ width $\mathrm{x}$ $300 \mathrm{~mm}$ height) glued to the polystyrene layer. VII: polystyrene layer. VIII: glass plate (480mm width x $300 \mathrm{~mm}$ height $\mathrm{x} 2 \mathrm{~mm}$ thick) placed between the fluorescent tubes and the thermal stations. IX: temperature sensor inserted in the lower row tubes (only one sensor is displayed).
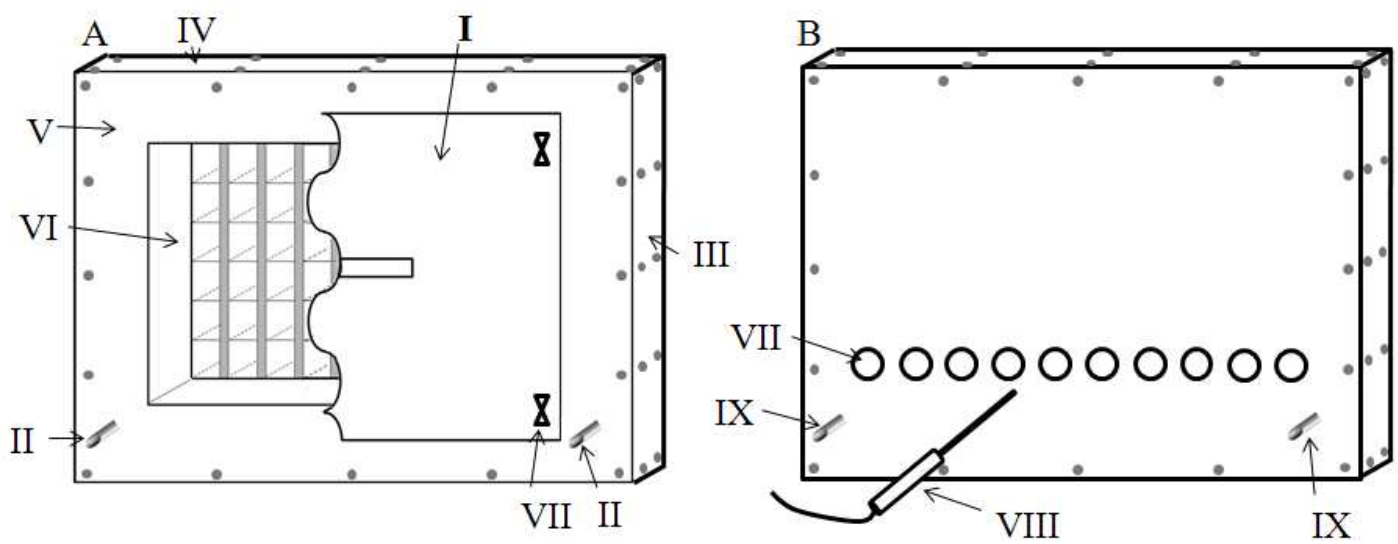

Figure 5 - A. Finishing of the anterior face of the entire apparatus, showing four thermal stations of the block. I: removable lid (partial view) (520mm width $\mathrm{x} 400 \mathrm{~mm}$ height) to allow access to the thermal stations. II: copper tube $(\phi=6 \mathrm{~mm})$ at the input of the groove in the additional plate. Covering lateral (III), superior (IV) and frontal (V) galvanized iron plates (1.5mm thick) screwed to the frame (inferior plate is not showed). VI: turned edge (50mm depth) of the frontal covering plate. VII: one of the fastening screws of the lid. Final dimensions of the apparatus: $675 \mathrm{~mm}$ width $\mathrm{x}$ $490 \mathrm{~mm}$ height $\mathrm{x} 440 \mathrm{~mm}$ depth. Dimensions of the "window" at the frontal face of the block for accessing the thermal stations: $490 \mathrm{~mm}$ width $\times 310 \mathrm{~mm}$ height. B. Back view of the apparatus with holes (VII) through which temperature sensors (VIII) can be inserted in the lowest row of tubes. IX: copper tube at the output of the groove in the additional plate. 


\section{Germination technique}

The seeds were germinated in PVC $18 \mathrm{~mm}$ wide $\mathrm{x}$ $9 \mathrm{~mm}$ height $\times 250 \mathrm{~mm}$ long wiring duct (referred to as a tray) lined with three strips of qualitative filter paper kept saturated with the distilled water. The trays were placed inside $25 \mathrm{~mm}$ in diameter $\mathrm{x}$ $250 \mathrm{~mm}$ long glass assay tubes closed by stainless steel stoppers. A glass tube with a tray containing 50 seeds was inserted at each aluminum tube of the block so that each of the six rectangular tubes of each thermal station held a glass tube, with the exception of the lowest tube within which was inserted a PT100 probe for monitoring the temperature. Thus, a total of five replicates per temperature with 50 seeds per replicate were used. The seeds were considered germinated once the radicle emerged and had geotropic curvature. Observations were made at $24 \mathrm{~h}$ intervals and the germinated seeds were withdrawn as soon as recorded. A germination test was also carried out in climatized room at $26 \pm 1{ }^{\circ} \mathrm{C}$, with the seeds being germinated in Petri dishes $(\phi=50 \mathrm{~mm})$ on three sheets of qualitative filter paper saturated with distilled water. The dishes (three repetitions per treatment, with 50 seeds per repetition) were kept under white light $\left(41.5 \mu \mathrm{mol} . \mathrm{m}^{-2} . \mathrm{s}^{-1}\right)$ and darkness. Darkness was obtained with the Petri dishes being placed within black polyethylene boxes. The germination (radicle protrusion) was recorded as referred above. The germination variables computed were the final percentage of germinated seeds (germinability) and the average germination rate (Labouriau \& Osborn 1984). The distributions of the cumulative germination percentages were analyzed and the parameters were determined through a thermal time $\left(\theta_{\mathrm{g}}\right)$ model (Garcia-Huidobro et al. 1982). To find the values of base temperature $\left(\mathrm{T}_{\mathrm{b}}\right)$, median thermal time $\left(\theta_{50}\right)$ and the standard deviation $\left(\sigma_{\theta}\right)$ of the thermal time distribution, the cumulative daily germination percentages at 7.5, 10.0, 14.0, 17.0, 20.0 and $23.0{ }^{\circ} \mathrm{C}$ were transformed to probit and plotted against the respective $\theta_{\mathrm{g}}\left(=\left[\mathrm{T}-\mathrm{T}_{\mathrm{b}}\right] \mathrm{t}_{\mathrm{g}}\right)$ on a logarithmic scale, where $\mathrm{T}$ was the experimental temperature and $\mathrm{t}_{\mathrm{g}}$ the time for germination of a percentage $g$ (Bradford, 1995).

\section{RESULTS AND DISCUSSION}

Temperature recordings taken along the time showed that the temporal temperature variations within the thermal stations were relatively small $\left(\mathrm{SE}<0.1{ }^{\circ} \mathrm{C}\right)$ (Fig. 6). Thus, if the room temperature was kept relatively constant, the temperature gradient in the block was controlled primarily by the thermostatic baths settings. If the room temperature was not controlled, the temperature within a given thermal station could vary according to the time of the day, as reported by Labouriau and Cavalcanti (1996). An increase in the temperature by approximately $2.4{ }^{\circ} \mathrm{C}$ (mean value for all the stations) was observed inside the block when the fluorescent tubes inside the apparatus were turned on with the temperature settings of $50{ }^{\circ} \mathrm{C}$ ("warm" bath) and $7{ }^{\circ} \mathrm{C}$ ("cold" bath) and a thermal gradient from $10.5^{\circ} \mathrm{C}$ to 40.8 ${ }^{\circ} \mathrm{C}$ (in darkness) (Fig. 7). Temperature is expected to arise with light on since the fluorescent tubes produce a certain amount of heat even if the electronic reactors are placed outside the block. Otherwise, the lighting inside the block did not change the slope of the relationship between the temperature and the position of each thermal station along the gradient block, that is, the temperatures along the block only rose when the internal illumination of the block was on, whereas the variation of the thermal-gradient was similar both under white light and darkness (Fig. 7). In order to assure the repeatability of the temperature gradient when both light and darkness conditions were required for the germination assay, it was advisable to use the block with the fluorescent tubes on and wrapping the specimen tubes in aluminium foil or other suitable opaque material. In the model presented here the average temperatures fit a linear relationship with the position of the thermal stations along the block $\left(\mathrm{R}^{2}\right.$ $>0.98$ ) under both white light and in darkness, thus repeating the performance of the gradient blocks described by Labouriau (1977) and Labouriau and Agudo (1987). The mirror glued to the removable lid at the frontal face of the apparatus was an attempt to improve the irradiance distribution inside the aluminium tubes of each thermal station by reflecting the light from the fluorescent tubes placed at the back face of the block. However, a light gradient was observed when the irradiance was recorded at different positions along the tube (Fig. 8). This feature allowed the apparatus to be used to test light gradients as well as thermo-gradients. A relatively low irradiance $\left(<5 \mu \mathrm{mol} \cdot \mathrm{m}^{-2} \cdot \mathrm{s}^{-1}\right)$ was observed at a distance range up to $15 \mathrm{~cm}$ from the front edge of 
the aluminium tube. Then the irradiance started increasing and attained $\cong 11$ and $21 \mu \mathrm{mol} \cdot \mathrm{m}^{-2} \cdot \mathrm{s}^{-1}$ at $25 \mathrm{~cm}$ and $30 \mathrm{~cm}$ from the edge, respectively (Fig. 8 ). Thus, with the present set of fluorescent tubes, the maximum irradiance obtained was nearly 21 $\mu \mathrm{mol} . \mathrm{m}^{-2} . \mathrm{s}^{-1}$ close to the glass plate at the back face of the thermal stations, near the light source. Such an irradiance level appeared to be enough to promote the germination of a number of photoblastic seeds, as shown by the small-seeded species Musanga cecropioides, Nauclea diderrichii and Milicia excels (Kyereh et al. 1999). In the present study, the seeds of P. tomentosa (a small-seeded species) were sowed near to each other on the opposite side of the tray relative to the mouth of the assay tube within which the tray was, assuring that the seeds inside a assay tube were exposed to a similar irradiance $\left(\cong 11 \mu \mathrm{mol} \cdot \mathrm{m}^{-2} \cdot \mathrm{s}^{-1}\right)$. Such a procedure is not advised for large seeds, since they occupy a relatively large space along the tray and thus they would be subjected to a gradient of light, as well as the seed itself may interfere with the distribution of light inside the tube. Otherwise, an advantage of that gradient is that germination assays can be carried out with simultaneous variation of light and temperature.

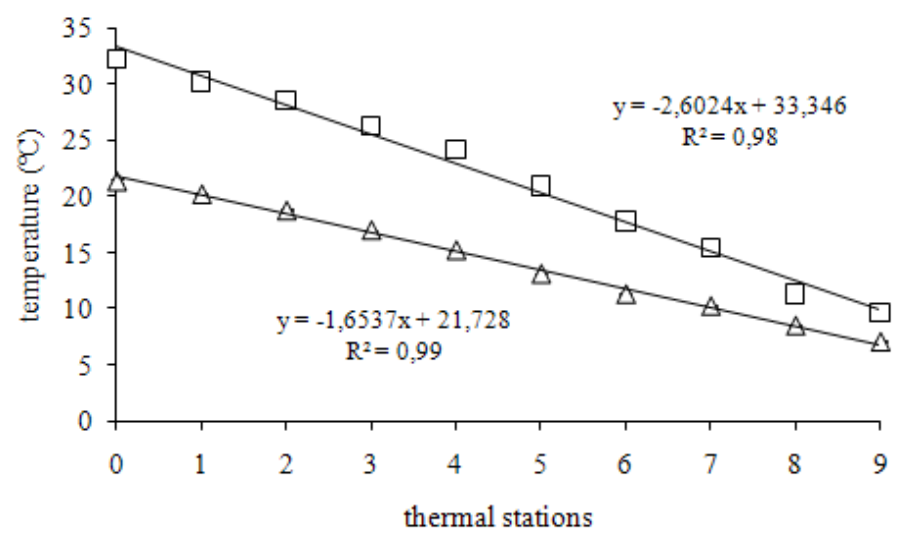

Figure 6 - Upper series ( $)$ : mean variations $( \pm S E)$ of the temperature in the thermal stations, with temperature of the thermostatic baths settled at $35{ }^{\circ} \mathrm{C}$ and $4{ }^{\circ} \mathrm{C}$, respectively. Lower series $(\Delta)$ : mean temperature ( $\pm \mathrm{SE}$ ) for observations taken $12 \mathrm{~h}$ apart during 21 days (temperature settings, $25{ }^{\circ} \mathrm{C}$ and $5{ }^{\circ} \mathrm{C}$ ). Room temperature around $22{ }^{\circ} \mathrm{C}$ and light turned on within the thermal gradient block.

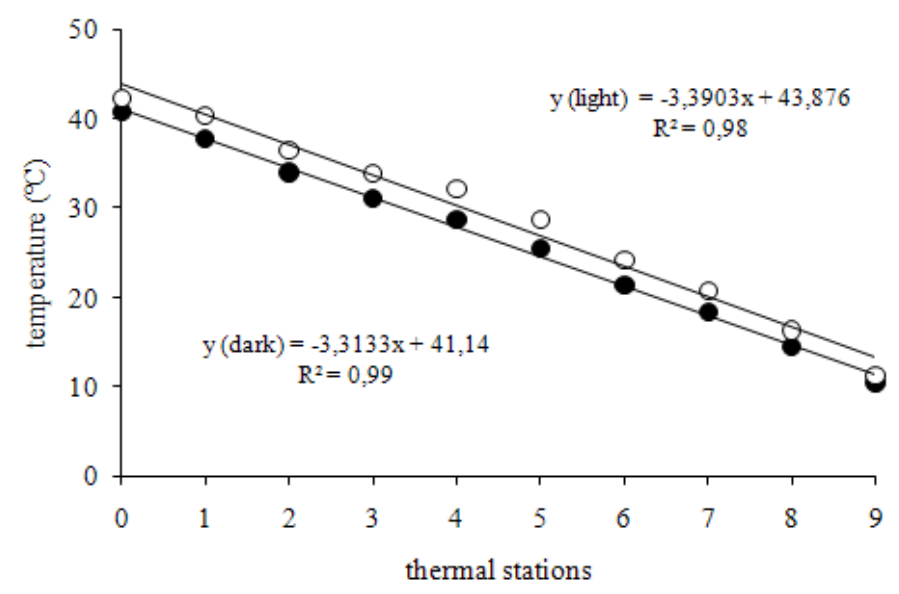

Figure 7 - Temperature recordings in the thermal stations with the fluorescent tubes in the thermalgradient block turned on (o) and off $(\bullet)$. Temperature settings: "warm" bath, $50{ }^{\circ} \mathrm{C}$; "cold" bath, $7^{\circ} \mathrm{C}$. 


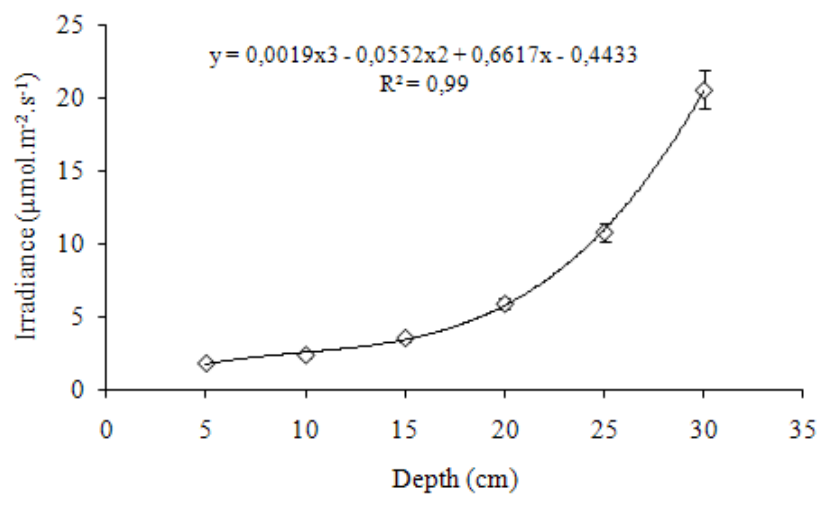

Figure 8 - The measured irradiances ( $\mu$ mol.m-2.s-1) as a function of the sensor position (depth) in the aluminum tubes of the thermo gradient block. Values in the abcissae are the distances $(\mathrm{cm})$ from the frontal edge toward the back edge of the tube. Symbols are the means $( \pm \mathrm{SE})$ of recordings taken at different each tube of the thermal stations.

The germinability of $P$. tomentosa seeds in the thermal-gradient apparatus was higher than $80 \%$ at 14,17 and $20^{\circ} \mathrm{C}$, and it decreased at both upper and lower temperatures, whereas the germination rate appeared to decreases linearly with temperature in the range of 7.5 to $28{ }^{\circ} \mathrm{C}$ (Fig. 9). Although the highest value for the germination rate was obtained at $28^{\circ} \mathrm{C}$, the germinability was only $2 \%$ and did not differ significativelly from zero (confidence interval, $\alpha=0.05$ ). Simão et al. (2007), working with Hylocereus setaceus seeds, also reported that the highest germination rate was obtained at a temperature $\left(45^{\circ} \mathrm{C}\right)$ in which only $7.5 \%$ of the seeds germinated. Thus, the germination must be seen not only in terms of the physiological homogeneity of the seed batch measured by the germinability - but also as a kinetic process taking place with a certain rate and is limited by different partial processes (Labouriau, 1983). The treatments of 17, 20 and $23{ }^{\circ} \mathrm{C}$ for $P$. tomentosa seeds were also assayed in darkness in the thermo-gradient and no germinated seeds were observed in such treatments, suggesting that $P$. tomentosa seeds have an absolute light requirement, as reported by Pons and Toorn (1988) for Plantago major. In general, the results presented here were in agreement with Dousseau et al. (2008) who reported that $P$. tomentosa seeds were photoblastic (lightrequiring) and the germination was optimal at the constant temperatures of 15 and $20{ }^{\circ} \mathrm{C}$. Fig. 9 also shows an assay performed with $P$. tomentosa seeds germinated in climatized room at $26{ }^{\circ} \mathrm{C}$ under an irradiance of $41.5 \mu \mathrm{mol} . \mathrm{m}^{-2} . \mathrm{s}^{1}$. The germinability was $81 \%$ against $19 \%$ recorded for the seeds incubated at the same temperature in the thermogradient block under a lower irradiance

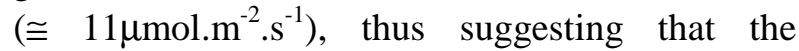
response of $P$. tomentosa seeds to temperature could be influenced by the irradiance. Bell (1994) reported that the effects of light exposure on the germination of Eucalyptus marginata forest understorey species were most evident when the temperatures were above the optimum. That may be the case of $P$. tomentosa, but more detailed studies are needed. Adaptations are necessary, such as the use of lamps with higher light intensities, in order to improve the irradiance levels inside the block, thus allowing the apparatus that can be used both for high and low-irradiance requiring seeds. Otherwise, the conclusions drawn from the thermal-gradient block assays should be considered for a given irradiance, such as $P$. tomentosa. A base (or minimum) temperature $\left(\mathrm{T}_{\mathrm{b}}\right)$ around $3{ }^{\circ} \mathrm{C}$ was estimated for $P$. tomentosa seeds, suggesting that the seeds could germinate at relatively low temperatures. The plotting of the germination time courses on a thermal time scale showed that the model could be applied to the germination studies with this species (Fig.10). Once $T_{b}$ has been identified and the total thermal time to germination is known, the actual time to germination at any temperature can be calculated with the assumptions that the instantaneous germination rate is independent of thermal history (Hardegree and Van Vactor, 1999). In the present 
study, a requirement of $106 \pm 27$ degrees-day was found for $50 \%$ of the $P$. tomentosa seeds to germinate from the relationship displayed (Fig.10B). If $\theta_{50}=\left(\mathrm{T}-\mathrm{T}_{\mathrm{b}}\right) \mathrm{t}_{50} \therefore \mathrm{t}_{50}=\theta_{50} /\left(\mathrm{T}-\mathrm{T}_{\mathrm{b}}\right) \therefore$ $\mathrm{t}_{50}=106 /(\mathrm{T}-3.1)$, the time for germination of $50 \%$ of the seeds $\left(\mathrm{t}_{50}\right)$ at a given temperature $(\mathrm{T})$ could be estimated.

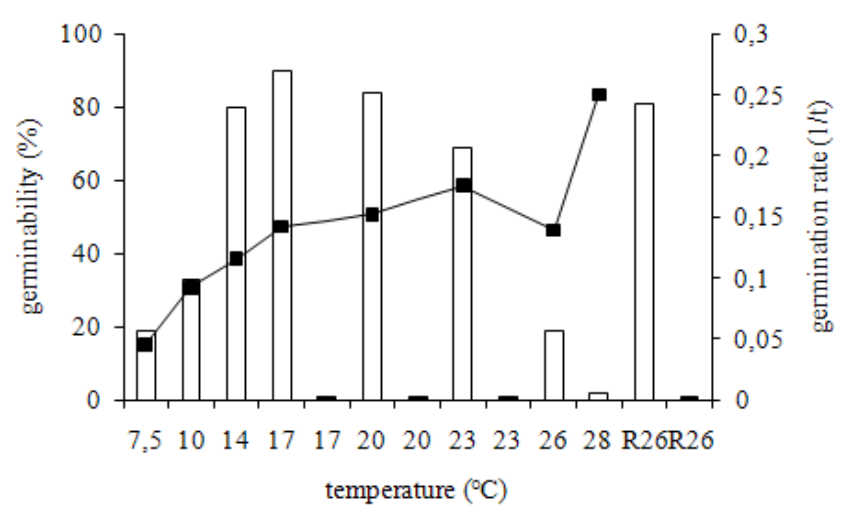

Figure 9 - Temperature dependence on the germinability (bars) and germination rate (line) of Plantago tomentosa seeds after 21 days under white light (mean irradiance 10.7 $\mu$ mol.m-2.s-1) (open bars) and darkness (dark bars) in the thermal gradient block. For darkness $\left(17{ }^{\circ} \mathrm{C}, 20^{\circ} \mathrm{C}\right.$ and $23{ }^{\circ} \mathrm{C}$ only) the glass tubes with the seeds were wrapped with aluminum paper sheet. Experimental temperatures: $7.5^{\circ} \mathrm{C} ; 10{ }^{\circ} \mathrm{C} ; 14^{\circ} \mathrm{C} ; 17^{\circ} \mathrm{C}$; $20{ }^{\circ} \mathrm{C} ; 23{ }^{\circ} \mathrm{C} ; 26{ }^{\circ} \mathrm{C} ; 28{ }^{\circ} \mathrm{C} ; 30^{\circ} \mathrm{C}$ and; $32{ }^{\circ} \mathrm{C}$. Germination was null at $30{ }^{\circ} \mathrm{C}$ and 32 ${ }^{\circ} \mathrm{C}$. Germinability (final percentage) at $26 \pm 1{ }^{\circ} \mathrm{C}$ in darkness (dark bar) and under white light (open bar) (mean irradiance of $41.5 \mu$ mol.m-2.s-1) of P. tomentosa seeds kept in climatized room (R26) is also presented.
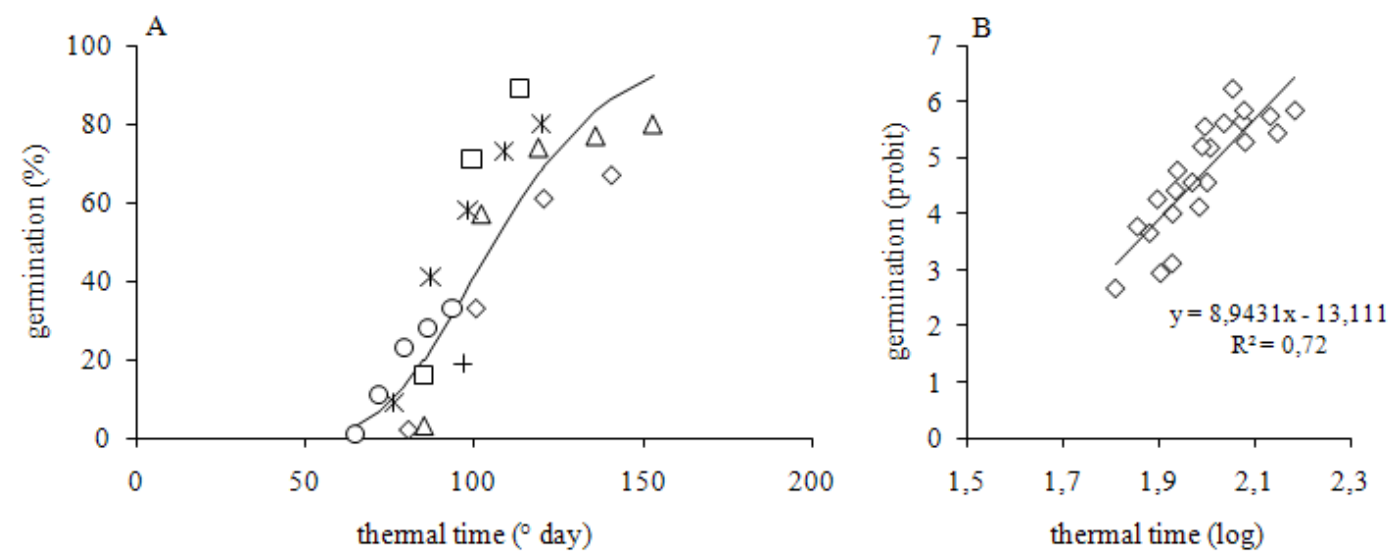

Figure 10 - The course of cumulative germination in thermal time scale $(\mathrm{A})$ at $7.5{ }^{\circ} \mathrm{C}(+), 10{ }^{\circ} \mathrm{C}$ $(0), 14{ }^{\circ} \mathrm{C}(*), 17{ }^{\circ} \mathrm{C}(), 20{ }^{\circ} \mathrm{C}(\Delta)$ and $23{ }^{\circ} \mathrm{C}(\diamond)$ for Plantago tomentosa seeds. Thermal time $(\theta \mathrm{g})$ is the actual time (days) multiplied by the difference between experimental $(\mathrm{T})$ and base temperature $\left(\mathrm{Tb}=3.1^{\circ} \mathrm{C}\right)$. The curve in $(\mathrm{A})$ is derived from the relationship between probit of the germination and $\log$ of $\theta \mathrm{g}$. Assays were carried out in the thermal gradient block under white light (mean irradiance $10.7 \mu$ mol.m-2.s$1)$. 
One of the limitations pointed for the previous models of thermo-gradient blocks was the lack of internal illumination (Labouriau, 1977; Labouriau and Agudo, 1987), which did not allow the germination assays with light treatments. The present thermo-gradient apparatus overcame to a large extent such a limitation, allowing the experiments with light-requiring seeds, as demonstrated for photoblastic P. tomentosa seeds. With the aid of the block described here, some parameters related to the temperature dependence on the germination of that species could be estimated, showing that the apparatus was suitable for the studies on the temperature dependence of photoblastic seeds. On the other hand, a limitation referring to the seed size persisted yet: the light gradient within a thermal station restrained the use of larger seeds, thus, only small-seeded species could be assayed in order to avoid a repetition to be exposed to a wide range of irradiance and assured that samples had a reasonable number of seeds. New adaptations are also needed in order to improve the irradiance inside the block.

\section{ACKNOWLEDGEMENTS}

The author thanks CNPq for productivity research grant.

\section{RESUMO}

Este trabalho descreve um bloco termo-gradiente com iluminação interna, adaptado para estudos com sementes que requerem luz para germinar. Para se aferir o desempenho do equipamento, este foi usado num experimento sobre o efeito da temperatura na germinação de sementes fotoblásticas de Plantago tomentosa. Com o protótipo aqui descrito, alguns parâmetros da resposta dessa semente à temperatura puderam ser estimados, mostrando que o equipamento pode ser usado em estudos sobre a dependência térmica da germinação de sementes fotoblásticas

\section{REFERENCES}

Bell, D.T. (1994), Interaction of fire, temperature and light in the germination response of 16 species from the Eucalyptus marginata forest of south-western Western Australia. Aust. J. Bot., 42, 501-509.
Bradford, K. (1995), Water relations in seed germination. In-Seed Development and Germination, ed. J. Kigel and G. Galili. Marcel Dekker Inc, New York, p. 351-396.

Brites, V.L.C, Penteado, C.H.S, Domingos, R.N e Luciano, E.A. (1986), Dispositivo para o estudo de preferências térmicas de insetos. Cienc. Cult., 38, 167-170.

Cardoso, V.J.M. (1994), Montagem de um sistema de gradiente térmico para investigação da dependência da temperatura da germinação de sementes. Arq. biol. tecnol., 37(4): 755-761.

Cardoso, V.J.M. and Pereira, F.J.M. (2009), Dependência térmica da germinação de sementes de Drymaria cordata (L.) Willd. Ex Roem. and Schult. (Cariophyllaceae). Acta Bot. Bras., in press.

Dousseau, S., Alvarenga, A.A., Arantes, L.O., Oliveira, D.M. and Nery, F.C. (2008), Germination of Plantago tomentosa Lam. Seeds: influence of the temperature, light and substrate. Cienc. Agrotec., 32, 438-443.

Garcia-Huidobro, J., Monteith, JL. and Squire, GR. (1982), Time, temperature and germination of pearl millet (Pennisetum typhoides) I. Constant temperature. J. Exp. Bot., 33, 288-296.

Hardegree, S.P. and Van Vactor, S.S. (1999), Predicting germination response of four cool-season range grasses to field-variable temperature regimes. Environ. Exp. Bot., 41, 209-217.

Kyereh, B., Swaine, M.D. and Thompson, J. (1999), Effect of light on the germination of forest trees in Ghana. J. Ecol., 87, 772-783.

Labouriau, L.F.G. (1977), A thermal-gradient block for germination experiments. Rev. Bras. Biol., 37, 295305.

Labouriau, L.F.G. (1983), A Germinação das Sementes, Secretaria Geral da OEA, Washington, 174p.

Labouriau, L.F.G. and Agudo, M. (1987), On the physiology of seed germination in Salvia hispanica L. I. Temperature effects. An. Acad. Bras. Cienc., 59, 37-56.

Labouriau, L.F.G. (1978), Seed germination as a thermobiological problem. Radiat. Environ. Biophys., 15, 345-366.

Labouriau, L.G. e Cavalcanti, R.B. (1996), Um bloco de gradiente térmico de fácil construção, para experimentos termobiológicos. Rev. Bras. Fisiol. Veg., 8, 149-156.

Labouriau, L.G. e Osborn, J.H. (1984), Temperature dependence on germination of tomato seeds. J. therm. biol., 9, 285-294.

Machado-Neto, N.B., Prioli, M.R., Gatti, A.B. and Cardoso, V.J.M. (2006), Temperature effects on seed germination in races of common beans (Phaseolus vulgaris L.). Acta Sci. Agron., 28, 155-164.

Peters, N.C.B. (1990) A temperature gradient bar for seed germination and biological investigations. Seed Sci. Technol., 18, 765-773. 
Pons, T.L. and Toorn J. (1988), Establishment of Plantago lanceolata L. and Plantago major L. among grass. I. Significance of light for germination. Oecologia, 75, 394-399.

Santos, D.L. and Cardoso, V.J.M. (2001), Thermalbiological aspects on the seed germination of Cucumis anguria L.: influence of the seed coat. Rev. Bras. Bot., 24, 435-440.

Simão, E., Socolowski, F. and Takaki, M. (2007), The epiphytic Cactaceae Hylocereus setaceus (Salm-Dick ex DC) Ralf Bauer seed germination is controlled by light and temperature. Braz. arch. biol. technol., 50, 655-662.

Souza, G.M. and Cardoso, V.J.M. (2000), Effects of different environmental stresses on seed germination. Seed Sci. Technol., 28, 621-630.
Thompson, K. and Whatley, J.C. (1984), A thermogradient bar apparatus for the study of the germination requirements of buried seeds in situ. New Phytol., 96, 459-471.

Vasquez-Yanes, C. (1975), The use of a thermogradient bar in the study of seed germination of Ochroma lagopus SW. Turrialba, 25, 328-330.

Received: March 03, 2009; Revised: June 09, 2009; Accepted: July13, 2010. 